\title{
Ethnic Factor as a Prerequisite of Ethnopolitical Conflict
}

\begin{abstract}
The actuality of this article lies in understanding the role of the ethnic factor in the ethnopolitical conflict. Especially, the article examines the peculiarities of the usage of the term "ethnicity", approaches to understanding ethnicity in Ukrainian and foreign science, as well as differences in the understanding of ethnic (national) groups (minorities) as the subjects of confrontation. It traces how derivative concepts from the formal definition of ethnicity are comprehended and realized in different theoretical structures. In the article conditions under which the ethnic factor heralds imminent danger and is politicized are defined.
\end{abstract}

Keywords: ethnicity, ethnic identity, ethno-political conflict, ethnos, nationality, ethnic (national) group

The attention of scholars to the ethnic factor as a major conflict-triggering factor has increased in recent decades. This is primarily due to the fact that ethnic differences often arise as a source of ethno-political confrontation. Processes of ethnic identity strengthening became particularly important in the era of "ethnic renaissance" since these processes are marked with a significant conflict-triggering capacity and a permanent ethno-political tension. Therefore, understanding the role of the ethnic factor in the ethno-political conflict gains increasing importance and it becomes especially crucial in the current global modernization processes, where ethnicity and the related ethnic identity actually arise as a basis for confrontation.

Ukrainian and foreign scholars devoted many publications to research issues of ethno-political conflict and ethnic component, which is an integral feature of this type of conflict. In particular, considerable attention to features of the course of conflict on ethnic grounds is paid by such Ukrainian scholars as W. Evtukh, O. Kartunov and A. Kisse. Numerous works are also devoted to the issues of ethnicity. It is worth to mention a solid study of western scholars on this subject by 
D. Horowitz, T. Gurr, G. Hicks, W. Sollors, etc. However, some issues, particularly those related to the uniqueness of the interpretation and understanding of ethnicity and derivative phenomena, remain quite vague, which complicates further research in the field of ethno-political conflict.

The purpose of the article is to investigate the role of the ethnic factor in the process of ethno-political conflicts and to reveal main contradictions it this phenomenon.

Modern world modernization processes, despite active promotion of democracy and pluralism, cause interethnic disparities, rivalries for material benefits, stimulating the intensification of ethnic, national feelings and exacerbating the need to protect ethnic identity, thus provoking accentuation of conflicting factors. Therefore, to understand the phenomenon of the modern ethno-political conflict, first of all, it is important to understand the profound conditions of its emergence, where an important factor of this type of conflict is the ethnic diversity of society: the existence of different ethnic groups with different political and social status, religion, cultural or other orientations. However, it is needed to bear in mind that the relationships between groups with different ethnicity and the conflicting interests are the source of conflict and not the existence of variety of groups.

Currently, in the world there are between 4,000 and 6,000 ethoses and over 200 independent states ${ }^{1}$. Analysing and understanding conditions of the ethnic groups existence is a prerequisite for the harmonious development of civilization.

In the context of the ethnic factor study we should start by saying that Western science is more inclined to use the term "ethnicity" to indicate the set of such concepts as "ethos", "nation", "ethnic/national group", etc. ${ }^{2}$. Although the concept of "ethnicity" is derived from the Greek "ethos", in the West the term "ethos" has come into general scientific practice. Even if these concepts, at a first glance, are pretty close, they have their own attributive shade of meaning, which should not be neglected when operating with data concepts. In addition, the concept of "ethnicity" has a specific definition in the national scientific school, which will be discussed later.

Regarding the interpretation of the term "ethos", the Western scholars explain this phenomenon primarily as a biological and then social phenomenon, which stands in opposition to the views of Ukrainian and Russian scholars. Based on the definition of famous Ukrainian scientist W. Evtukh, who mainly emphasizes the social aspect of ethos, ethos is a historical form of social grouping of people that is

O. Kartunov, Western Theories of Ethnicity, Nations and Nationalism, Kiev 2007, p. 45.

D. Horowitz, Ethnic Identity, Harvard 1975, p. 114. 
capable of sustained centuries-old collective existence and self-reproduction ${ }^{3}$. It is reasonable to understand ethos as a complex of ethno-biological and ethno-social factors, the priority of which depends on the historical conditions of each ethnic group formation. Ethos is formed from the physical needs of the people to unite for self-preservation and self-identification. It is a variety of human self-organization and it is a prerequisite of nation forming.

It is also important to pay attention to the concept of "nation", where nation is a result of the ethos development and politicization. This article is based on understanding the nation in $\mathrm{M}$. Weber's interpretation, who regarded the nation as a community of feelings that adequately manifested in the own state, therefore, the nation is a community which normally tends to create the state ${ }^{4}$. This definition was supplemented by E. Smith, who said that nations, as a source of political power, are able to realize themselves only in their own states ${ }^{5}$. It is necessary to understand nation as a concept close to the ethos, but with a distinct political consciousness and desire for state building. The nation is the result of a political integration while ethos is the result of a historical one.

Ethnological approach to the study of ethnic-based conflict also needs to investigate the peculiarities of ethnic and national groups (minorities) as subjects of confrontation.

First of all, it should be noted that the ethnic group is a part of ethos, but due to various circumstances it is forced to live outside the ethos, but feels a relationship with it. O. Kartunov regards that the essential characteristic of an ethnic group is that "being in alien ethnic environment, it retains its own characteristics, and often acts as an organized community". Ethnic group could be a fully-fledged subject of conflict only if the high level of collective consciousness and inner group organization is maintained, and the group apprehends itself as an alien ethnic formation in their place of residence. This means that ethnic group retains all or main characteristics of ethnicity, such as: language, culture, religion, peculiarities of mentality, and so on. Unlike ethnic groups, national group - is a part of the ethnic group that created its own state and formed the nation ${ }^{7}$. It means that ethnic groups may not have their own state (e.g. Gypsies), which cannot be said about a national group.

3 V. Evtukh, Ethnic Minorities: Concepts, Features, Functions, Philosophical and Sociological Thought, 1994, No. 1-2, p. 164.

M. Weber, Favourites Separate Works, Moscow 1990, p. 615.

E. Smith, Nationalism and Historians, Kiev 1990, p. 287.

O. Kartunov, Introduction to Ethnopolitology, Kiev 1999, p. 123.

7 Idem, Western Theories of Ethnicity, Nations and Nationalism, Kiev 2007, pp. 45-46. 
It should be emphasized that international law uses the term "minority" to describe ethnic and national groups. Thus, minority, similarly as ethnic/national group is a group that separated from the native ethos (nation) but retained its identity in "foreign" territory and did not occupy a dominant position. Ethnic minorities live in the territory that is alien to their national identity, culture, history, and usually also religion and language.

An important fact is that about $90 \%$ of modern ethno-political conflicts are "conflicts between ethnic minorities and the majority".

It is worth noting that in a multi-ethnic state very often there are many unresolved questions with an ethnic connotation. Then, it can be assumed that the ethnic factor, as a determinant of ethnic and national feelings which can be mobilized during the dynamic development of society and inter-ethnic cooperation, is the main conflicting force in ethno-political collisions. The source of ethno-political conflict is an ethnic conflict and then a political one. Thus, for further analysis of ethno-political conflict it is needed to understand the essence of the phenomenon of "ethnicity".

The concept of "ethnicity" is complicated and controversial. Moreover, it is a rather new concept, first used by American sociologist D. Risman only in $1953^{9}$. There is a great deal of approaches both in Western and Ukrainian national schools concerning understanding of this phenomenon.

There are three main approaches to explaining ethnicity, analysis of which allows to reveal the essence of the phenomenon of ethnicity. These approaches are complementary and aimed at studying the same phenomenon from different sides, but they are not the only classification benchmarks of this area. Thus, the proponents of the Primordialism theory (E. Shils, E. Smith, M. Nowak, L. Gumilev, etc.) linked ethnicity with human nature and biological ties to their community as an inherent part of the beginning of life. Within Instrumentalism (D. Horowitz, K. Young, J. Bentley, etc.) ethnicity was studied as a social characteristic that unites people and is based on the ideology of ancestor kinship ${ }^{10}$. According to this theory, ethnicity was activated during confrontation. D. Horowitz notes that ethnicity and voluntary choice of group membership are dichotomic aspects that occupy different positions in the objective reality ${ }^{11}$. Thus, according to Instrumentalism, ethnicity is not a kind of characteristic that belongs to the sphere

\footnotetext{
8 Ibidem.

9 Ibidem.

10 M. Ross Howard, Ethnic Conflict and Its Management: A Narollian Analysis of a Worldwide Problem, Cross-Cultural Research, 1995, No. 29 (70), p. 72.

11 D. Horowitz, op. cit., p. 114.
} 
of human choice, though in this approach it is analyzed through subjectivism. Constructivism theory (E. Gellner, B. Anderson, etc.) interprets ethnicity as an artificially constructed understanding of ethnic differences that arises in the process of each ethnic group development. Ethnicity is a result of "a dense network of social interactions" ${ }^{\prime 2}$. W. Sollors notes that ethnicity is a mental structure and simultaneously the product of modern history. It is like a response to the current transformation processes ${ }^{13}$. Thus, although ethnicity bears primordial ethos' characteristics, it may be unconscious. The awareness and activation of ethnicity is caused by a number of factors, the main of which are interethnic communication and global transformation, democratization and globalization processes.

It is essential to understand what ethno-political conflict within abovementioned theories is.

Therefore, Primordialism considered conflict as an inalienable attribute of society; Instrumentalism noted that ethnicity became a part of masses' mobilization in the struggle for power and material resources, while Constructivism argued that conflict was a constructed phenomenon, where ethnicity did not always have a key role ${ }^{14}$. It is worth agreeing with the modern Russian researchers of ethnic processes (H. Shtein, V. Volkan and A. Obolonski), who believe that ethnicity is rooted in the nature of people, groups, applied to their origin, but meaningfully contained in the "people's minds"15. Thus, ethnicity is the basis of a meaningful process of individual, group, and ethos ethnogensis. These processes are based on the collective cohesive interrelated actions and mutual psycho-emotional perception and interpretation of political, cultural and social events.

Ethnicity as a phenomenon cannot be the primary motivating force for the struggle, because the prime mover that causes mobilization of ethnicity can be a tough economic politics or struggles for power between political leaders and parties. All of these factors affect the level of ethnic hostility or a sense of ethnic nationalism exacerbation ${ }^{16}$. Ethnicity, rather than being inherently political, is merely instrumental in protecting or advancing group or individual interests

12 Legal Mechanisms for the Settlement of Ethno-Political Conflict in Ukraine: Scientific Note, V.A. Koretsky Institute of State and Law, National Acedemy of Sciences of Ukraine, 2011, pp. 9-16.

13 W. Sollors, Beyong Ethnicity: Consent and Descent in American Culture, New York 1996, p. 18.

14 D. Haidai, Modern Approaches to the Study of "Ethnic Conflict", Actual Problems of National And World History: Collected Essays, 2009, No. 12, p. 162.

15 V. Volkan, National Problems Through Psychology Prism with Political Comment, Humanities and Modernity, 1992, No. 6, p. 32.

16 F. Pearson, Dimensions of Conflict Resolution in Ethnopolitical Disputes, Journal of Peace Research, 2001, No. 38 (8), p. 281. 
on the political arena ${ }^{17}$. Dissatisfied ethnopolitical interest becomes the basis of ethnic tension or ethnic conflict.

It is worth pointing out that ethnicity is the basis of all ethnic and political processes and gives strength to ethno-political conflict but it is not a determinant conflicting factor. Actually, as the driving force of conflicts with ethnic component most researchers consider a politicized ethnicity - the state in which ethnicity is no longer a passive characteristic of ethnic group (ethos). The main reason for the politicization of ethnic minorities, which in turn is a precondition of ethno-political conflict, is, above all, their unequal status as well as economic and political discrimination. The result of ethnicity politicization is a desire within the group not only to unite but to lead collective actions and fight for saving or defending their interests. The politicization of ethnicity is most active during a crisis, when there is some kind of threat to ethnicity or to the whole ethnic / national group. The ethnicity politicization involves the acquisition of political consciousness of the ethnic community, including the participation in political decision-making processes. Thus, the politicization of ethnicity is a kind of mobilizing force for decisive action. In this aspect it is important to mention T. Gurr, who noticed that the greater diversity of ethnic groups, that is, the more distinctive features between the groups, the easier it is to mobilize the masses to fight for identity, cultural and socio-political values ${ }^{18}$. In other words, ethnicity is a consciousness of differences, the subjective salience of differences that in some moments provokes mobilization around differences. It is a kind of relationship with emotional characteristics ${ }^{19}$. Thus, the role of ethnic conflict factor is determined by its ability to mobilize the masses on the basis of ethnic values for joint action.

There is a substantial link between ethnic emotions and politicized ethnicity. Ethnic emotions lead to ethnification, ethnic intolerance, competition, and eventually - violent conflict. Usually, negative ethnic emotions are stemming from historical memories of grievances, manipulation of ethnicity and factors that facilitate ethnic intolerance by political entrepreneurs and competition over resources and rights ${ }^{20}$. The same characteristics we observe in politicized ethnicity. Moreover, negative emotions speed up the process of politicization. Politicized ethnicity

17 F.M. Coronel, The Moro and the Cordillera Conflicts in the Philippines and the Struggle for Autonomy, Ethnic Conflicts in Southeast Asia, 2005, p. 112.

18 T.R. Gurr, Why Minorities Rebel: A Global Analysis of Communal Mobilization and Conflict since 1945, International Political Science Review, 1993, No. 14, p. 189.

19 J.D. Eller, From Culture to Ethnicity to Conflict, USA 2002, p. 9.

20 B. Blagojevic, Causes of Ethnic Conflict: A Conceptual Framework, http://www.globalaffairsjournal.com/wp-content/uploads/2011/08/CausesofEthnicConflict.pdf, (accessed 12.03.2014). 
accompanied by ethno-national emotions has a destructive effect on a country's development process.

Since there is a close relationship between "ethnicity" and "identity" 21 the attention should be paid to the fact that ethnic identity is also presented as a condition for the consolidation and mobilization of ethnic groups. In general, identity is the result of the ethos self-determination (self-identification) ${ }^{22}$. Thus, the selfdetermination, as mental-cognitive process is the basis of ethnic identity. It is also important to notice the differences in terms of ethnic and national identity according to the works of famous Ukrainian researcher I. Kresina. National identity, in contrast to ethnic identity, is a dynamic historical and social category, based on conscious individual choice.

Ethnic identity is an extremely steadfast phenomenon: to change identity means to accept another and therefore adopt another religion, cultural traditions, language, etc ${ }^{23}$. Implicitly, such changing of ethnic identity does not mean changing all these attributes, but even to deny one is extremely difficult, if not impossible.

As A. Kisse, who investigates ethnic identity as one of the sources that cause conflict, rightly noted: "ethnic identity cannot be eliminated, but its conflicting potential can be reduced" 24 . Ethnicity and ethnic identity play an important role in ethno-political conflicts. It is important to understand that ethnic identity can be in latent state, but also it can actualize at certain moments, like ethnicity, depending on the content and forms of social interaction. During the conflict, intragroup identity along with intragroup solidarity grows, generating hostility to alien ethnic groups. It is necessary to emphasize the exceptional importance of ethnic identity, which is an essential feature of the ethnic group, in contrast to language, territory, common origin, economic relations, bonds, political associations, culture, and religion that are not necessarily inherent to each ethnic group. Ethnic identity is a "higher level" of ethnic consciousness, which means that the internal unity of the ethnic group and its distinctive features are based on the contrast between "their" group and other groups. In times of crisis this contrasting obtains hostile features and attributes negative characteristics to other groups. All

21 G. Hicks, Introduction: Problems in the Study of Ethnicity, Massachusetts 1977, p. 4.

22 Ethno-Political Processes in Ukraine: Regional Characteristics, Institute of Political and Ethnic studies of Ukraine, 2011, p. 43.

23 M. Mishali-Ram, Ethnic Diversity, Issues, and International Crisis Dynamics 1918-2002, Journal of Peace Research, 2006, No. 43, p. 585.

24 A. Kisse, Ethnic Conflict: Theory and Practice of Management. Political Science Review: Monograph, Kiev 2006, p. 65. 
these factors complicate interethnic communication and co-existence in a multiethnic state.

Thus, ethnicity itself is a neutral characteristic of ethnos (ethnic groups); in other words its main purpose is to promote internal unity and identity, which cannot be said of politicized ethnicity. Identity is the result of a process of selfdetermination of ethnic groups, where the self-determination as a mental cognitive process is the basis of ethnic identity. The central point of this article is that the primary source of ethno-political conflict is ethnic confrontation followed by a political one. Politicized ethnicity arises as a paramount conflict factor in ethno-political conflicts and confrontations. Ethnic (national) group (minority) is a fully-fledged subject of a conflict provided it maintains collective consciousness, where ethnicity and degree of politicization determine the level of consciousness of subjects of ethno-political confrontations. The role of the ethnic factor in a conflict is determined by its ability to unite the masses on the basis of ethnic values. Thus, the ethnic factor, which is mobilized during inter-ethnic interaction in times of crisis, actualizes ethnic identity and intra-ethnic (group) identity and has the greatest conflict-triggering potential in an ethno-political conflict. It should be noted that the basis of the ethnic factor and ethno-political conflict are communication processes, analysis of which will facilitate the optimization of ethno-political conflict management, so special attention has to be paid to further scientific exploration. 